\title{
Effects of latex from "Amapazeiro" Parahancornia amapa (Apocynaceae) on blowfly Chrysomya megacephala (Diptera: Calliphoridae) post-embryonic development
}

\author{
Paloma M. Mendonça ${ }^{a, *}$, Mariana G. Lima ${ }^{b}$, Luis R.M. Albuquerque ${ }^{c}$, Mario G. Carvalho $^{c}$, \\ Margareth M.C. Queiroz ${ }^{\mathrm{a}}$ \\ a Laboratório de Transmissores de Leishmanioses - Setor de Entomologia Médica e Forense, Instituto Oswaldo Cruz, Fiocruz, Avenida Brasil, 4365 \\ Manguinhos, CEP: 20045-900, Rio de Janeiro, RJ, Brazil \\ ${ }^{\mathrm{b}}$ Instituto de Biologia, Departamento de Ciências Fisiológicas, Universidade Federal Rural do Rio de Janeiro, Brazil \\ c Departamento de Química, Instituto de Ciências Exatas, Universidade Federal Rural do Rio de Janeiro, Brazil
}

\section{A R T I C L E I N F O}

\section{Article history:}

Received 27 May 2010

Received in revised form

21 December 2010

Accepted 7 January 2011

\section{Keywords:}

Latex

Diptera

Apocynaceae

Chrysomya megacephala

Biological control

\begin{abstract}
A B S T R A C T
Nowadays, insect control is usually carried out using chemical insecticides, but insect resistance and other negative side effects have prompted the search for alternatives. Biopesticides provide a positive alternative to synthetic pesticides because they have low impact on the environmental, low toxicity to humans and low costs among other advantages. This research was carried out to evaluate the activity of Parahancornia amapa (Huber) Ducke (Apocynaceae) lyophilized latex on the post embryonic development of Chrysomya megacephala (F.) (Diptera: Calliphoridae). Larvae treated with 1.0\% latex showed a shorter post embryonic development period (larval, pupal and newly hatched larvae to adult); whereas larvae treated with 3.0\% latex provoked a prolongation of these periods. Viability (53\%) was also very low at the newly hatched larvae to adult period for larvae treated with $3.0 \%$ latex, indicating that latex from $P$. amapa at high concentrations could change $C$. megacephala post embryonic development.
\end{abstract}

(c) 2011 Elsevier B.V. All rights reserved.

\section{Introduction}

The Chrysomya species are the primary invertebrate consumers of decomposing organic matter (Braack, 1986). The blowfly can survive in different habitats, since they are ecologically diverse. The larvae of these flies are able to develop in various substrates, such as decomposing organic matter, feces, garbage and copses (Guimarães et al., 1978; Queiroz et al., 1999).

Chrysomya megacephala (F.) (Diptera: Calliphoridae), known as the Oriental latrine blowfly, was introduced into southern Brazil in the 1970s and nowadays is found

\footnotetext{
* Corresponding author. Tel.: +55 212562 1846; fax: +55212562 1846. E-mail address: palomamm@ioc.fiocruz.br (P.M. Mendonça).
}

throughout the entire continent (Greenberg, 1988; Wells, 1991). This fly has great importance to humans and animals, because larva causes myiasis and adult acts as a physical carrier of pathogens, such as enteroviruses, enterobacteria, protozoan cysts and oocysts, helminths and fungi (Greenberg, 1971, 1973).

Chemical insecticides used for insect control are especially dangerous in urban areas since these products can affect man and others animals, pollute the air, water and even enter the food chain. So along with the appearance of insect resistance and other negative side effects, the search for alternative forms of control has become important.

Efforts are continuously being made to find alternative substances for insect control in order to decrease the use of chemical insecticides. Biopesticides provide an alternative to synthetic pesticides because they have low impact on 


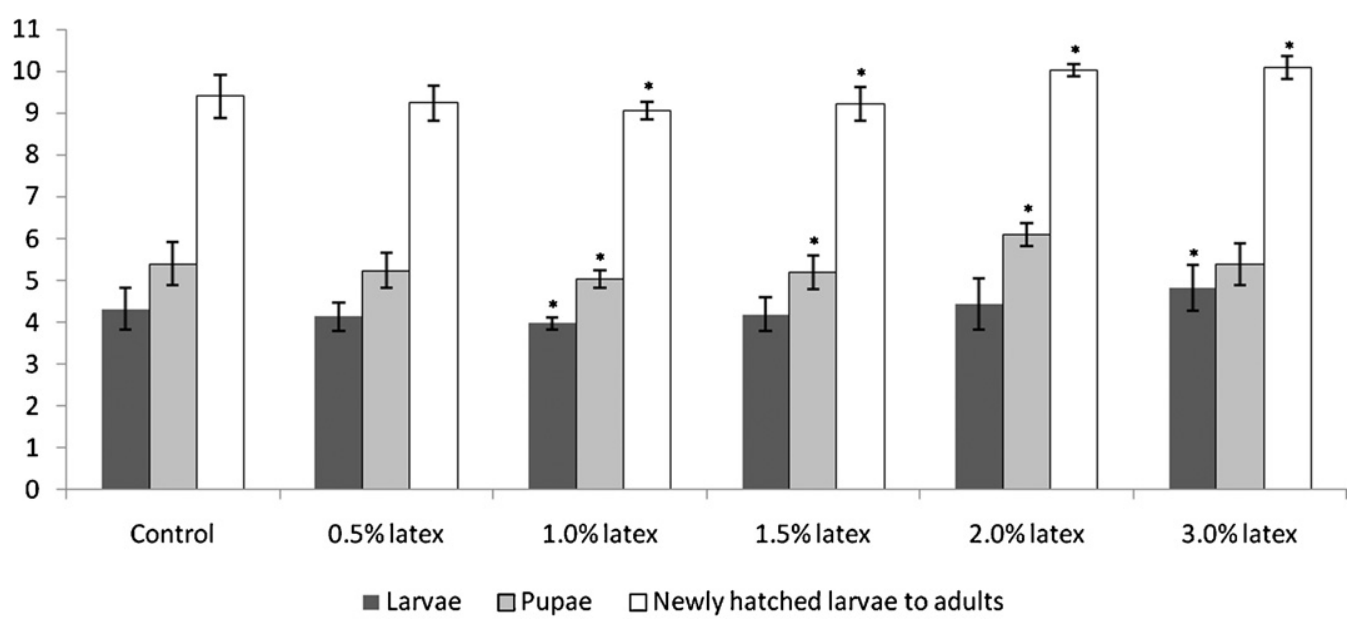

Fig. 1. Duration (day) of larval, pupal and newly hatched larvae to adults development period of Chrysomya megacephala (Diptera: Calliphoridae) topically treated with different concentrations of latex extracted from Parahancornia amapa (Apocinaceae). *Significative different from control group.

the environmental, low toxicity to humans, low costs as well as other advantages (Liu et al., 2000).

According to Feinstein (1952), approximately 2000 species of plants representing more than 170 families are said to have insecticidal properties. Plants from the family Apocynaceae are widely used as medicinal plants and as insecticides. Mathew et al. (2009) tested Saraca indica (Fabales: Caesalpiniaceae), Clitoria ternates (Fabales: Fabaceae) and Nyctanthes arbor-tristis (Fabales: Oleaceae) against the mosquito vectors (Diptera: Culicidae) of malaria, lymphatic filariasis and dengue at India (Anopheles stephensi, Culex quinquefasciatus and Aedes aegypti, respectively) and tests resulted in the identification of the potential plant extracts for mosquito larval control.

Parahancornia amapa (Huber) Ducke is a tree found in the Brazilian Amazon, especially in Amapa state. It is known as "amapa" or "amapazeiro" and the bark and latex are used by the natives as a tonic, anti-syphilitic medicine and to treat digestive diseases (Sobrinho et al., 1991; Monteles and Pinheiro, 2007). Natives also reported its use as an insect repellent. This research evaluates the activity of $P$. amapa lyophilized latex on the post embryonic development of $C$. megacephala.

\section{Materials and methods}

The Oswaldo Cruz Institute in the state of Rio de Janeiro rears and maintains colonies of $C$. megacephala following the methodology described by Queiroz and Milward-deAzevedo (1991). The cultures used here were kept in cages at room temperature and were supplied ad libitum with water and sugar. Protein in the form of equine meat was given to stimulate oviposition; and the insects readily oviposited on this medium. The new generation was reared following the same methodology and newly hatched larvae from the second laboratory-hatched generation were used in the experiments.

The latex from P. amapa was collected from the specimen identified by Benedito Vitor Rabelo (IEPA) in Amapa state; deposited example ( $\left.\mathrm{N}^{\circ} 07231\right)$ in the Herbário Amapaense (HAMAB). The lyophilized latex from $P$. amapa was diluted in distilled water to obtain the test concentrations. Five different concentrations $(0.5,1.0,1.5,2.0$ and 3.0\%) were used and a control group treated with distilled water.

Latex was applied topically to newly hatched larva bodies using groups of 50 insects ( $1 \mu \mathrm{L} / \mathrm{larva})$. The bioassays were performed in triplicate. Newly hatched larvae were grouped in a Petri dish, covered with absorbing paper moistened with destilled water and the latex was applied using micropipettes on the larvae for $5 \mathrm{~min}$. After treatment, the paper with the larvae were transferred and placed onto equine putrefied meat $(50 \mathrm{~g})$, with a proportion of $1 \mathrm{~g}$ of meat for each larva, to guarantee enough food for maximum development. After reaching maturity, the larvae spontaneously abandoned the diet and were collected. These larvae were individually weighed and transferred to glass tubes containing vermiculite to one-fourth of their volume and covered with cotton plugs. Daily observations were made until the adults emerged. After emergence, the adults were separated by gender.

The experiments were maintained in acclimatized chambers set at $27^{\circ} \mathrm{C} \pm 1{ }^{\circ} \mathrm{C}$ and $70 \pm 10 \% \mathrm{RH}$. The results were analyzed by ANOVA $(P \leq 0.05)$, the mean values were compared by the Tukey-Kramer test at the 0.05 significance level and the sex ratio was tested by chi-square (Sokal and Rohlf, 1979).

\section{Results}

In this study, C. megacephala treated with 3.0\% latex showed an increase in the larval period duration when compared to control group (4.8 and 4.3 days, respectively). On the other hand, larvae treated with $1.0 \%$ latex showed a shorter duration of this period (3.9 days) and differed significantly from control group (Fig. 1). Duration of the pupal period was also shorter for flies treated with $1.0 \%$ latex and longer in $2.0 \%$ latex (5.0 and 6.0 days, respectively), differing from control group (5.4 days) and from the other 


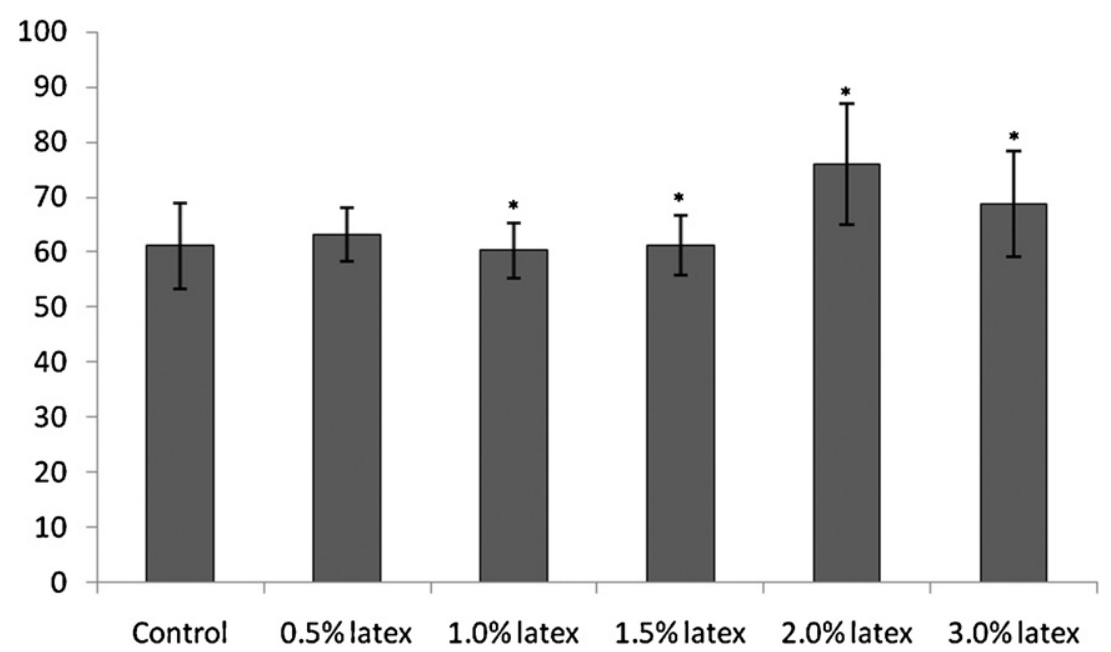

Fig. 2. Larval weight (mg) of Chrysomya megacephala (Diptera: Calliphoridae) topically treated with different concentrations of latex extracted from Parahancornia amapa (Apocinaceae). *Significative different from control group.

treatments. These treatments showed no difference among themselves, but all of them were statistically different from control group (Fig. 1). 1.0\% latex showed the shortest duration from the newly hatched larvae to the adult period (9.0 days) and 2.0 and 3.0\% latex the longest duration for this period (10.0 days for both treatments). Duration of control group was 9.4 days and differed significantly from all the other treatments (Fig. 1).

Fig. 2 shows the results of the weights of the different groups. Larvae from the $1.0 \%$ latex group were the lightest $(60.2 \mathrm{mg})$ and from $2.0 \%$ latex they were the heaviest $(76 \mathrm{mg})$, while the control group weighed $61 \mathrm{mg}$.

C. megacephala were specially affected by $3.0 \%$ latex where viability was low at the larvae and newly hatched larvae to adult periods (65 and 53\%, respectively), while all other treatments and the control group showed viabilities higher than $60 \%$ (Fig. 3). $0.5 \%$ latex showed the highest viability, for all periods observed, but larvae pupated in the medium (equine meat) used to breed the larvae (Fig. 3).
In this research, all development periods (larval, pupal and newly hatched larvae to adult) were shorter for larvae from the $1.0 \%$ latex group and also they weighed less than the other latex concentrations.

\section{Discussion}

According to d'Almeida et al. (2001), duration and viability from the newly hatched larvae to the adult period seem to be the most efficient parameter to evaluate the substance efficacy, because it prevents distortions between the larval and pupal periods. These periods are strongly influenced by abiotic factors such as temperature, humidity and photoperiod. el-Shazly et al. (1996) tested the effect of an ethanolic extract of leaves from Nerium oleander (Apocynaceae) against Muscina stabulans (Diptera: Muscidae). This extract delayed larval and pupal duration, suppressed oviposition and decreased adult longevity of survivors, affecting directly on endocrine system of the insects. In

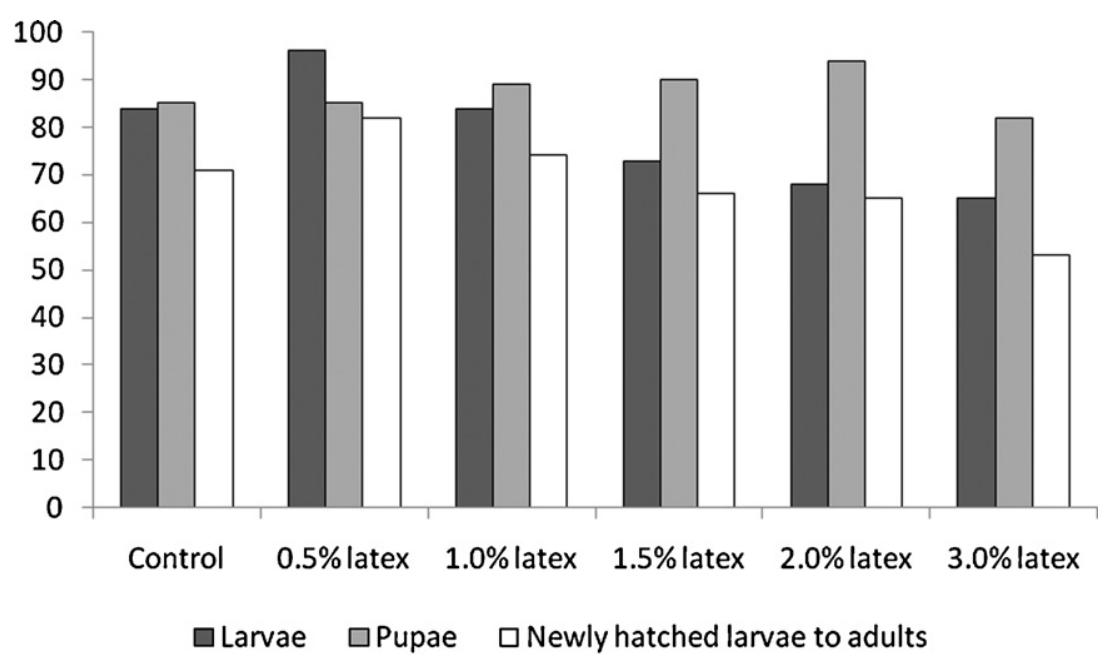

Fig. 3. Viabilities (\%) of larval, pupal and newly hatched larvae to adults development period of Chrysomya megacephala (Diptera: Calliphoridae) topically treated with different concentrations of latex extracted from Parahancornia amapa (Apocinaceae). 
this study, $0.5 \%$ latex showed viabilities higher than control group for all development periods observed. The larvae did not leave the medium, they pupate inside the equine meat what avoid the effect of the natural loss occurred during this important process. Under natural conditions, larvae that did not leave the carcass are more susceptible to the effects of predators and parasitoids (Vinson and Iwantsch, 1980) and this effect of the latex from P. amapa should be better investigated.

Dipterous larvae usually leave the diet when the quantity of nutrients available is not enough or the competition among larvae is very high. In some cases, larvae stay a longer time on the diet to compensate the low quality or quantity of nutrients (Santos and Borja, 1997). Some substances can alter the insect's endocrine system, by acting directly on growth control and development or on hormone production (Cabral et al., 1999). According to Miyazawa et al. (1994), licarin A, a substance extracted from plants, interferes directly with fruit fly Drosophila melanogaster (Diptera: Drosophilidae) development period.

Some necrophagous diptera are better adapted to pupate even when they have the final weight below the average previously estimated for the other species. According to Von Zuben (1998), the minimum weight necessary for $C$. megacephala to become a pupa is $30.1 \mathrm{mg}$. All pupae from this research weighed more than the minimum and this explains the high pupal viability found in all treatments.

Results found in this research are in agreement with other authors who have studied the effects of products extracted from plants against the post-embryonic development of muscoids diptera (Peckia (Peckia) chrysostoma (Diptera: Sarcophagidae) and C. megacephala) (Cabral et al., 2007a,b). These same authors also found alterations in the life cycle, development period viabilities and morphological alterations, mainly at the higher concentrations, similar to our findings.

In conclusion, an effort has been made to evaluate the role of plant latex in fly control. The results showed that $P$. amapa alters $C$. megacephala development at high concentrations and could influence the pupation at lower concentration. This then opens up the possibility for further investigations using extracts with different solvents and even the pure substance. Some tests in this sense are already in progress.

\section{Acknowledgments}

We thank David Graham Straker for his helpful English review. This work was supported by grants from Fundação de Amparo a Pesquisa do Estado do Rio de Janeiro (FAPERJ), Instituto Oswaldo Cruz (IOC/FIOCRUZ) and Conselho Nacional de Desenvolvimento Científico e Tecnológico - Fundação Oswaldo Cruz (PAPES V).

\section{References}

Braack, L.E.O., 1986. Arthropods associated with carcasses in the northern Kruger National Park. S. Afr. J. Wildlife Res. 16, 91-98.
Cabral, M.M.O., Kelecom, A., Garcia, E.S., 1999. Effects of the lignan pinoresinol on the moulting cycle of the bloodsucking bug, Rhodnius prolixus, and of the milkweed bug, Oncopeltus fasciatus. Fitoterapia 70, 561-567.

Cabral, M.M.O,, Mendonça, P.M., Gomes, C.M.S, Barbosa-Filho, J.M. Queiroz, M.M.C., Mello, R.P., 2007a. Biological activity of neolignans on the post-embrionic development of Chrysomya megacephala. Fitoterapia $78,20-24$

Cabral, M.M.O., Mendonça, P.M., Gomes, C.M.S., Barbosa-Filho, J.M., Dias, C.S., Soares, M.J., Queiroz, M.M.C., 2007b. Biological activity of yangambin on the postembryonic development of Chrysomya megacephala (Diptera: Calliphoridae). J. Med. Entomol. 44, 249255.

d'Almeida, J.M., Ferro, C.L., Fraga, M.B., 2001. Desenvolvimento Pósembrionário de Chrysomya putoria (Diptera: Calliphoridae) em Dietas Artificiais. Acta Biol. Leopoldensia 23, 4-7.

el-Shazly, M.M., Nassar, M.I., el-Sherief, H.A., 1996. Toxic effect of ethanolic extract of Nerium oleander (Apocynaceae) leaves against different developmental stages of Muscina stabulans (Diptera: Muscidae). J. Egypt. Soc. Parasitol. 26, 461-473.

Feinstein, L., 1952. Insecticides from plants. In: Insects: The Year Book of Agriculture. U.S.D.A, Washington, DC, 229 pp.

Greenberg, B., 1971. Flies and diseases. In: Ecology, Classification and Biotic Associations, vol. I. Princeton University Press, Princeton, 856 pp.

Greenberg, B., 1973. Flies and diseases. In: Biology and Diseases Transmission, vol. II. Princeton University Press, Princeton, 845 pp.

Greenberg, B., 1988. Chrysomya megacephala (F.) (Diptera: Calliphoridae) collected in North America and notes on Chrysomya species present in the New World. J. Med. Entomol. 25, 199-200.

Guimarães, J.H., Prado, A.P., Linhares, A.X., 1978. Three newly introduced blowfly species in Southern Brazil (Diptera: Calliphoridae). Rev. Bras. Entomol. 22, 53-60.

Liu, S.Q., Shi, J.J., Cao, H., Jia, F.B., Liu, X.Q., Shi, G.L., 2000. Survey of pesticidal component in plant. In: Benjing, L. (Ed.), Entomology in China in $21^{\text {st }}$ Century. Science $\&$ Technique Press, China.

Mathew, N., Anitha, M.G., Bala, T.S.L., Sivakumar, S.M., Narmadha, R., Kalyanasundarum, M., 2009. Larvicidal activity of Saraca indica, Nystanthes arbor-tristis and Clitoria ternatea against three mosquito vector species. Parasitol. Res. 104, 1017-1025.

Miyazawa, M., Ishikawa, Y., Kasahara, H., Yamanaka, J., Kameoka, H., 1994. An insect growth inhibitory lignan from flower buds of Magnolia fargesii. Phytochemistry 35, 611-613.

Monteles, R., Pinheiro, C.U.B., 2007. Plantas medicinais em um quilombo maranhense: uma perspectiva etnobotânica. Rev. Biol. Ciên. Terra 7, 38-48.

Queiroz, M.M.C., Milward-de-Azevedo, E.M.V., 1991. Técnicas de criação e alguns aspectos da biologia de Chrysomya albiceps (Diptera: Calliphoridae), em condições de laboratório. Rev. Bras. Zool. 8, 75-84.

Queiroz, M.M.C., Norberg, N.A., Maure, E.A.P., Toledo, R.F., Gazeta, G.S., Dutra, A.E.A., Rodrigues-Guimarães, R., 1999. Veiculação de bactérias patogênicas por moscas sinantrópicas coletadas em restaurantes, hospitais e feiras da Baixada Fluminense, Rio de Janeiro, Brasil. Anais do XIV Congresso Latinoamericano de Parasitologia, México, 102 pp.

Santos, M.J.P., Borja, G.E.M., 1997. Estudo comparativo do Desenvolvimento Pós-embrionario de Fannia pusio (Wiedemann, 1830) (Diptera: Fannidae) em Diferentes Substratos. Arq. Biol. Tecnol. 40, 253 261.

Sobrinho, D.C., Hauptli, M.B., Appolinário, E.V., Kollenz, C.L.M., Carvalho, M.G., Braz-Filho, R., 1991. Triterpenoids isolated from Parahancornia amapa. J. Braz. Chem. Soc. 2, 15-20.

Sokal, R.R., Rohlf, F.J., 1979. Biometry: The Principles and Practice of Statistics in Biological Research. W. H. Freeman and Co., San Francisco, 188 pp.

Vinson, S.B., Iwantsch, G.F., 1980. Host suitability for insect parasitoids. Ann. Rev. Entomol. 25, 397-419.

Von Zuben, C.J., 1998. Comportamento de Oviposturas Individuais, Percentagem de Eclosão e Peso Larval Mínimo para Pupação em Populações de Chrysomya megacephala (F.). Ann. Entomol. Soc. Bras. 27, 525-533.

Wells, J.D., 1991. Chrysomya megacephala (Diptera:Calliphoridae) has reached the continental United States: review of its biology, pest status and spread around the world. J. Med. Entomol. 28, 471-473. 